\title{
Towards The Issue of Pricing in the Field of Works to Meet the State and Municipal Needs
}

\author{
${ }^{1}$ Olga A. Vorobyeva, ${ }^{2}$ Pavel Z. Ivanishin, ${ }^{3}$ Elena Yu. Kovalkova \\ ${ }^{1,2}$ Kazan Federal University \\ ${ }^{3}$ Kazan Branch of the Russian State University of Justice \\ Email: olga.tattrans@yandex.com
}

Received: 02 ${ }^{\text {nd }}$ November 2018, Accepted: $28^{\text {th }}$ November 2018, Published: 31 ${ }^{\text {st }}$ December 2018

\begin{abstract}
The paper deals with certain legal issues of pricing in the field of procurement of goods, works and services for state and municipal needs. The analysis made it possible to identify the main problems of pricing in the field of state and municipal procurement in modern conditions. The issues related to the lack of unity in the construction work pricing methods; non-competitive environment for the implementation of relations in the contract system; the vagueness of the nature of the price of the state and municipal contract as a condition of the contract were considered.

At the same time, pricing in the field of procurement of goods, works and services to meet state and municipal needs is a system of interrelated actions of participants in the contract system in the field of procurement, organized in the most consistent manner in order to increase the efficiency of budget spending. In this regard, the features of pricing in the procurement of goods, works and services for state and municipal needs were studied.
\end{abstract}

\section{Keywords}

Pricing, Price, Initial (Maximum) Contract Price, Procurement, Contract System, State and Municipal Needs, State and Municipal Contract, Procurement Efficiency, Methods for Calculating the Initial (Maximum) Contract Price

\section{Introduction}

At the moment, the problems of determining the price of a state and municipal contract are of particular relevance, since it must not only correspond to the task of achieving effectiveness of budget expenditures, but also the effectiveness of procurement of goods, works, services, and also adequately reflect the current price level.

Federal law dated 05.04.2013 N 44-FZ "On the contract system in the field of procurement of goods, works, services for state and municipal needs" (hereinafter - the Federal Law \# 44) [1] in paragraph 2 of article 34 defines the contract price as the essential condition and establishes the following: "When concluding a contract, it is indicated that the contract price is firm and is determined for the entire term of the contract, and in cases established by the Government of the Russian Federation, the indicative value of the contract price or the price formula and maximum contract prices set by the customer in the documentation on the purchase... ". The purpose of setting a price as an essential condition is quite simple and clear - effective and reasonable spending of budget funds.

\section{Methods}

A complex of methods was used (the induction and deduction methods, the method of analysis and synthesis, the method of ascent from the abstract to the concrete, the comparison method), what has made it possible to most reliably investigate the complex and multifunctional system of price formation relationships when concluding contracts when performing contract works for state and municipal needs.

The theoretical analysis of the regulatory framework and the practice of its legal implementation made it possible to consider pricing for contract work for state and municipal needs as a mechanism for ensuring public interests. Analyzing the individual facts, and then be grouping and systematizing them, we reveal the general and the particular in them.

The analysis is accompanied by a synthesis that helped penetrate the essence of the system under study. The method of comparison allowed us to determine the differences or commonality of the object under study with adjacent categories. The method of induction and deduction, in relation to research, allowed us to move from individual elements to forming a holistic view of the nature of price in relations arising from the performance of contractual work for state and municipal needs and made it possible to combine all stages of pricing in this area and draw particular conclusions.

\section{Results and Discussion}

The analysis of the contractual relations system in the sphere of contracting for the provision of state and municipal needs makes it possible to speak of contradictions between the ideal theoretical pricing model and reality. According to the Order of the Ministry of Economic Development of the Russian Federation dated October 2, 2013 N 567 [2], the justification of the contract price is mandatory for the customer, is calculated with the application of reference information and this justification is placed in the public domain on the Internet. Pricing according to Federal Law N44 goes through several stages (procurement price planning; making procurement with determining the contractual price; financial control in the field of procurement). 
However, as practice shows, this model is imperfect. When planning the implementation of the procurement, the main disadvantage is the lack of clarity in determining the mechanisms for forming the initial (maximum) contract price (IMCP) for the performance of contract work. The legislator proposes a number of methods that should be used in determining the initial (maximum) contract price (comparable market price method (market analysis); regulatory method; tariff method; design estimate method; cost method). At the same time, this value does not usually have a real link to the contract price, but only gives an approximate average value that will be used as a starting point at the beginning of trading, i.e. starting price for competitive procurement procedures carried out by state or municipal customers [3].

The accuracy of determining the initial (maximum) contract price is a crucially important condition, since further the reduction factor is determined from the initial estimated cost (initial (maximum) contract price) and as a result forms the value of each estimate line determining the final contract price, which is firm and not subject to change (Part 2 of Art.34 FZ 44).

It should be noted that the state expertise procedure does not save the situation, since the estimates submitted for the examination are usually consolidated, without division into separate positions and without specification of the technique of accounts (for example, the winter appreciation may not be previously taken into account due to climate forecasts). This situation could be rectified through the introduction of a legal norm according to which the Customer is obliged (in Article 33 of the Federal Law 44 - "may") to include into the documentation for the procurement the design and estimate documentation that has already passed the state examination procedure. Thus, the need to justify the initial (maximum) contract price as a separate procedure disappears, and the price value of the design and estimate documentation will be the initial (maximum) contract price, which is not subject to further dispute.

It should also be noted that the requirement for the availability of project documentation in full will allow procurement participants to form a proposal for the execution of the contract. In this case, if the customer did not include in the documentation in full the design and estimate documentation, it did not establish the requirements for the volume of purchased works. The Ministry of Economic Development and the Federal Antimonopoly Service of Russia adheres to this position. [4, Letter of the Ministry of Economic Development of Russia dated April 20, 2017 N D28i-1623 // SPS Consult.]

The positions of the courts on the question of whether it is necessary to include design and estimate documentation in the procurement documentation differ.

It is also necessary to highlight such a problem as the inability of a contractor to estimate the real value of the contract in cases where the customer puts up a lot with a general description of the object for auction, without actually linking to the design and estimate documentation (which either does not exist or did not pass a state expertise). Moreover, in the absence of project documentation, the contractor at the stage of concluding a contract has no idea about the calculation methods that will be applied later on when the work is performed.

The pricing procedure is complicated by a large number of calculation methods [4], for example: GESN which determines the standard cost of resources for pricing; FER which contains the cost of each price; FSTsM (collection of prices for materials) and FSEM (collection for the operation of machines). Thus, the GESN indicates that the estimated standards are divided into the following types: government estimates - GSN; industry estimated standards - OSN; territorial estimated standards - TSN; branded estimated standards - FSN; individual estimated standards - ISN. [5].

Meanwhile, the pricing system varies based on each method. For example, in a number of regions of Russia, an improved method of calculations similar by the type to GESN is being applied in the quarterly update of calculations for a unit of goods in relation to market prices, and in some regions, customers use the methods of 2001 similar by the type to TER and FER for the sake of economy, which are far behind to the current market prices even with the use of coefficients. Of course, one can also argue that the change in calculation methods, the amount of funding and other things should not affect the price of a state or municipal contract and the price is fixed and is not subject to subsequent change.

However, as the practice of work in the state order system shows that forming a contract which is essentially an adhesion contract, a customer includes into it provisions for a possible reduction in the contract price, for example, in case of adjustments to the design and estimate documentation or a change in the funding limit.

In this case, the position of the contract price, as a rule, is formulated as follows [1]

Item No. A: "The cost of this contract is N. All additional and unrecorded types of work are performed to the extent necessary for the manufacture and delivery of the Products, if this is provided for in this agreement, and paid for within the cost of this agreement. The cost of this contract is fixed and is determined for the entire term of the contract, subject to appropriate confirmation from the budget of the region concerned."

Item No. B: "In the event that after passing an examination in the state autonomous institution "Center for State Expertise", the cost of design and exploration work and other work and expenses, indicated in the calculation, exceeds the cost of the respective types of work and costs, as determined by the positive conclusion of the State autonomous institution "Center for State Expertise", the Parties are obliged to conclude an additional agreement to reduce the cost of work under this Contract in the manner provided for in this clause.

Item No. C: "Within three days from the receipt of a positive conclusion from the State autonomous institution "Center for State Expertise", the Contractor is obliged to issue and send to the Technical Customer an additional contract price reduction agreement signed by it. "The money paid by the State customer, which is the difference between the contract 
price specified in the Calculation, and the cost of the work determined by the positive conclusion of the State autonomous institution "Center for State Expertise", shall be returned to the budget within three days from the date of inclusion of the additional agreement into the Register of State Contracts. In case of violation of the term for return of funds specified in this paragraph, the Contractor shall pay a penalty in the form of surcharge for using other people's funds equal to $1.0 \%$ of the amount to be refunded for each day of delay from the date of receipt of overpaid funds to the Contractor's current account up to transfer of specified funds to the budget."

Quite often there are formulations in contracts stating that the Treasury Department of the Russian Federation has the right to inspect documentation submitted in accordance with the temporary provisions on financing the construction, design and survey, geological exploration and research works at the expense of the regional budget and targeted budget funds for compliance with its regulatory legal acts. Upon that, in the case of improper fulfillment of obligations, resulting in an overestimation of the cost of work, confirmed by the results of the audit carried out by the Treasury Department of the Russian Federation, the Customer has the right to collect a penalty in the amount of the overestimation of the completed works value. The Contractor has the right to purchase the products necessary for the implementation of the work produced by the enterprises of the region and included in the list of construction products, which has undergone an expert evaluation using the electronic trading resource "Exchange".

The courts take diametrically opposite positions in such cases (on the recognition of certain provisions of contracts null and void) [6]. Meanwhile, if there were properly prepared design estimates which had undergone a preliminary state examination procedure at the stage of planning procurement, such issues could have been avoided in court.

\section{Summary}

The system of relations in pricing in the field of procurement of goods, works and services for the provision of state and municipal needs is considered as a complex of legal and economic funds aimed at creating more effective budget expenditures. The main tool of this system is the formation of the initial (maximum) price of the contract. However, the analysis of individual pricing stages revealed the following problems: 1) the lack of terminological unity in the regulatory framework; 2) insufficiently thought-out methods for determining prices in construction; 3) insufficient financial control at the stage of planning the procurement; 4) changing the contract price at the stage of payment by the financial control authority is a violation of the principle of "pacta sunt servanda".

\section{Conclusion}

Improving the pricing efficiency in the procurement of goods, works and services to ensure state and municipal needs is necessary for the long-term and sustainable economic development in the Russian Federation aimed at ensuring a balance of public and private interests. Meanwhile, the legislative regulation in this area requires significant adjustments in order to increase competition, transparency and reduce the corruption component.

\section{Acknowledgements}

The work is performed according to the Russian Government Program of Competitive Growth of Kazan Federal University.

\section{References}

[1] Federal Law dated 05.04.2013 N 44-FZ (revised on 23.04.2018) "On the contract system in the procurement of goods, works, services for state and municipal needs" (with amendments and additions entered into force on 01.06.2018) // "Rossiyskaya gazeta" newspaper.04/12/2013, No. 80.

[2] Order of the Ministry of Economic Development of the Russian Federation dated October 2, 2013 , No. 567 "On Approval of Methodological Recommendations for the Application of Methods for Determining the Initial (Maximum) Contract Price, Contract Price to Be Concluded with a Single Supplier (Contractor, Executor)" // Housing and Public Utilities: the magazine of the manager and chief accountant. 2014 No. 1 (Part II), February 2014, No. 2 (Part II). Not published officially.

[3] Pakhomov Yu.G., Pakhomova L.M. Problem issues on determining the initial (maximum) contract price, the price of a contract concluded with a single supplier (contractor, executor) under the contract system // ARS ADMINISTRANDI. 2014 P.16-25.

[4] See, for example: Methodical recommendations on the development of single prices for construction, special construction, repair and construction works, installation of equipment and commissioning works № 75 / pr dated 09.02.2017; The method for application of the estimated norms № 1028 / pr dated 12/31/2016; Methodical instructions for determining the amount of overhead costs and estimated profit in construction carried out in the Far North regions and areas equated to them (MDS 81-34.2004), etc.

[5] Resolution of the Gosstroy of Russia (the Russian Federation State Committee for Construction, Architectural and Housing Policy) dated March 5, 2004 No. 15/1 (dated June 16, 2014) "On approval and introduction of the Methodology for determining the cost of construction products in the Russian Federation (together with "MDS 8135.2004...") // Informational bulletin on normative, methodical and typical project documentation.2004. No. 6.

[6] Resolution of the Arbitration Court of the North-West District dated April 13, 2016 on the case number A56-15476 / 2015 // APS Consultant. 